\title{
The Influence of Work Motivation, Compensation, and Work Environment on Employee Performance in the Housing and Land Areas of Denpasar City
}

\author{
Kadek Raditya Awidiya and I. Gusti Salit Ketut Netra
}

\section{ABSTRACT}

\begin{abstract}
The purpose of this study was to analyze the effect of work motivation on employee performance, the effect of compensation on employee performance, and the influence of the work environment on employee performance. This research is classified into quantitative research in the form of associative causality. The population in this study were 86 employees using a simple random sampling method so that as many as 71 employees were used as samples. The analysis technique used is Multiple Regression Analysis. The results obtained that work motivation has a positive and significant effect on employee performance, compensation has a positive and significant effect on employee performance, work environment has a positive and significant effect on employee performance.
\end{abstract}

Keywords: compensation, employee performance, work environment, work motivation.

\section{INTRODUCTION}

The growth and development of an organization depends on human resources. Therefore, the organization must be able to create situations and conditions that encourage employees to develop abilities and skills optimally as well as train employees and set organizational goals. The problem that arises is when mismanaging human resources will cause a decrease in employee performance. The company's success depends on how employees perform, efficiency, honesty, diligence and integrity.

Problems regarding employee performance are problems that will always be faced by management both in companies and in government institutions, therefore management needs to know the factors that affect employee performance. The three main factors that affect individual performance are the individual's ability to do the job, the level of effort devoted and the support from the organization or company. Factors that can affect employee performance will enable management to take the necessary policies, so as to improve employee performance to match the expectations of the company/organization.

One of the factors that affect employee performance is work motivation(Nurcahyani \& Adnyani, 2016). Work motivation is a person's encouragement to do work. If an employee has a strong drive that comes from internal and external, then the employee will be stimulated or motivated to do something well. In the end, encouragement, or stimulation both from within and from outside a person will produce good performance, and vice versa.

Motivation is one of the best tools to improve employee performance. Motivation is needed in a person so that motivation is one way to achieve a need to be achieved (Waeesor et al., 2016). their performance.
Submitted : September 07, 2021

Published : December 29, 2021

ISSN: 2507-1076

DOI: $10.24018 /$ ejbmr.2021.6.6.1092

Kadek Raditya Awidiya,

Faculty of Economy and Business, Udayana University, Bali, Indonesia.

(e-mail: radityaawidiya1@gmail.com) I. Gusti Salit Ketut Netra

Faculty of Economy and Business, Udayana University, Bali, Indonesia.

*Corresponding Author

(Santoni \& Suana, 2018). In other words, the emergence of motivation in a person because of hopes, goals, needs, drives, desires and goals (My, 2017). Employee motivation has become one of the important indicators for employees in evaluating whether someone is satisfied with their job. This can increase job satisfaction for employees in order to maintain the performance and quality of their employees

In addition to work motivation, a factor that can improve performance is compensation. Compensation is the remuneration provided by the organization/company to employees, which can be financial or non-financial in a fixed period (Padayachee, 2017). Compensation is very important for employees because by providing fair compensation with employee work standards can improve performance itself. With fair compensation, it can stimulate employee participation so that employees can work responsibly and have work participation in the company

Fair and appropriate compensation payments to employees can motivate employees to work as much as possible so that it can provide benefits for both parties, both employees and the company, where employees will get job satisfaction which will ultimately improve their performance and the company can achieve its goals and plans. previously determined. Compensation aims to motivate employees to be more active and disciplined at work, to be able to create mutual awareness among workers, to be able to do everything the company needs, to be able to mobilize and mobilize workers to behave to achieve good work results and improve

The work environment also affects employee performance. The work environment has an influence on the decline in employee performance caused by lack of flexibility in the 
work environment, work noise disturbance, lack of interpersonal relationships between superiors and subordinates. In order to achieve its goals, the company must create a work environment that is both physical and nonphysical.

H1: Work Motivation has a positive and significant effect on Employee Performance.

$\mathrm{H} 2$ : Compensation has a positive and significant effect on employee performance.

H3: Work Environment has a positive and significant effect on Employee Performance.

\section{Methodology}

This study uses a quantitative approach in the form of associative. The population in this study was 86 people. The sampling method used in this study is the Proportionate Stratified Random Sampling method with 71 people as samples in this study. Data collection in this study was carried out using the Questionnaire method. Questionnaire is a method of collecting data by giving respondents a list of written questions regarding work motivation, compensation, work environment and employee performance. The answers obtained from the respondents were given a score or value using a Likert scale of 1 to 5. This study uses multiple linear regression analysis to explain the effect of the independent variable on the dependent variable. The independent variable (Independent) is a variable that affects in this study, namely the variable work motivation (X1), compensation (X2), work environment (X3), while the dependent variable (dependent) is a variable that is influenced in this study is employee performance $(\mathrm{Y})$

\section{RESULTS}

Multiple linear regression method was used to determine the effect of work motivation (X1), compensation (X2), and work environment (X3) on employee performance (Y). This method was tested using SPSS version 26 data processing software. The effect of the independent variable on the dependent variable was tested with a significance level of $5 \%$ $(\alpha=5 \%)$.

TABLE I: MultiPle LiNEAR REGRESSION ANALYSIS RESUlTS

\begin{tabular}{|c|c|c|c|c|c|}
\hline \multirow[t]{2}{*}{ Variable } & \multicolumn{2}{|c|}{$\begin{array}{l}\text { Unstandardized } \\
\text { Coefficients }\end{array}$} & \multirow{2}{*}{$\begin{array}{c}\begin{array}{c}\text { Standardized } \\
\text { Coefficients }\end{array} \\
\text { Beta }\end{array}$} & \multirow[t]{2}{*}{$\mathrm{t}$} & \multirow[t]{2}{*}{ Sig. } \\
\hline & $\mathrm{B}$ & Std. Error & & & \\
\hline (Constant) & 2.239 & 1.593 & & 1.405 & 0.165 \\
\hline $\begin{array}{l}\text { Work Motivation } \\
\text { (X1) }\end{array}$ & 0.430 & 0.080 & 0.343 & 5.382 & 0.000 \\
\hline Compensation (X2) & 0.348 & 0.091 & 0.266 & 3.826 & 0.000 \\
\hline $\begin{array}{l}\text { Work Environment } \\
\text { (X3) }\end{array}$ & 0.510 & 0.082 & 0.454 & 6.259 & 0.000 \\
\hline R Square & & & 0.827 & & \\
\hline F. sig & & & 0.000 & & \\
\hline
\end{tabular}

The results of the simultaneous significance test (F-test) obtained the value of Sig. F of 0.000 . A significant value of $0.000<0.05$ means that the estimated linear regression model is feasible to use to explain the effect of work motivation, compensation, and work environment on employee performance. The adjusted $\mathrm{R}$ square value is 0.819 , which means that $81.9 \%$ of changes (up and down) in employee performance are influenced by work motivation, compensation, and work environment. While the remaining $18.1 \%$ is influenced by other variables that are not in the linear regression model.

\section{A. Work Motivation on Employee Performance}

Based on Table 1, the results of the t-test of the effect of work motivation on employee performance obtained a significance value of 0.000 with a positive regression coefficient of 0.430 . A significance value of $0.000<0.05$ indicates that $\mathrm{H} 1$ is accepted. These results indicate that work motivation has a positive and significant effect on employee performance, in other words the better the employee's work motivation, the employee's performance will increase. Employees feel that they are given the opportunity to experience personal growth and development. Leaders in the agency also highly appreciate the achievements of each employee. They can also work quite well in a fairly safe and comfortable working environment. The employees also feel that their basic needs have been adequately met while working in the agency. They also have good relationships with co-workers. Thus, these things provide encouragement for employees to work optimally and competitively which affects their respective performance (Ibrahim, 2017; Dwiputra \& Satrya, 2019; Mohamud et al., 2017; Ekundayo \& Babalola, 2018; Ali et al., 2016).

\section{B. Compensation for Employee Performance}

Based on Table I, the results of the t-test of the effect of compensation on employee performance obtained a significance value of 0.000 with a regression coefficient of 0.348 positive. A significance value of $0.000<0.05$ indicates that $\mathrm{H} 2$ is accepted. These results indicate that compensation has a positive and significant effect on employee performance, in other words the better the compensation given to employees, the employee's performance will increase. Employees who get achievements will be rewarded with higher career paths so that employees feel that what has been done with hard work will get something comparable. Of course, work with maximum results can occur because it is supported by complete facilities available at the agency. Thus what is obtained by the employee will certainly lead to a high sense of responsibility in every job to achieve good performance (Kimani et al., 2017; Onuorah et al., 2019; Reddy, 2020; Bharata, 2016; Akter \& Moazzam, 2016).

\section{Work Environment on Employee Performance}

Based on Table I, the results of the t-test of the effect of the work environment on employee performance obtained a significance value of 0.000 with a positive regression coefficient of 0.510 . A significance value of $0.000<0.05$ indicates that $\mathrm{H} 3$ is accepted. These results indicate that the work environment has a positive and significant effect on employee performance, in other words, the better the work environment, the employee's performance will increase. can work optimally with a sense of comfort. Lighting and work facilities are adequate in supporting the work of each employee. Cleanliness in the workplace is also felt by the majority of employees to be clean so that it gives a positive feeling to work. Relations with superiors and co-workers are also well established so that they can work together 
comfortably (Harini \& Kartiwi, 2018; Wilson, 2018; Widodo, 2018; Jayanti \& Syamsir, 2018).

\section{Research Limitations}

This research has been proposed and carried out in accordance with scientific procedures, however, there are still limitations in this study. The number of respondents was 71 employees and only from the Denpasar City Perkim Office, so that the results of this study may differ from the results of other studies in different research locations. There are many other variables that can affect employee performance outside the model described in this study. This study depends on the level of honesty of each respondent in stating every perceived situation so that there may be differences in the results of this study with the results of other studies using the same research variables.

\section{CONCLUSION}

This study aims to analyze the effect of work motivation, compensation, and work environment on employee performance at the Denpasar City Perkim Office. To analyze the influence between these variables, this study uses the IBM SPSS Statistics 26 software program. Based on the data analysis and discussion presented in the previous chapters, it can be concluded that work motivation has a positive and significant effect on employee performance. This means that the higher the work motivation of employees, the higher the performance that can be achieved by employees; Compensation has a positive and significant effect on employee performance. This means that the higher the compensation given to the employee, the higher the performance that can be achieved by the employee; and the work environment has a positive and significant effect on employee performance. This means that the better the existing work environment, the higher the performance that can be achieved by employees.

It is expected that the company can consider increasing salaries, guaranteeing career paths for outstanding employees, and increasing employee incentives so that they feel satisfied and not in vain for the sacrifices that have been made to work so that they feel it is worth working hard to achieve high performance and can pay more attention to the work atmosphere that can provide positive feelings for employees so that they can work with enthusiasm which will affect the achievement of each employee's performance.

\section{FUTURE RESEARCH}

For further research, it is expected to add other variables outside of this research model, besides that it can also use more samples or expand the scope of research locations in various different industries.

\section{REFERENCES}

Akter, N., \& Moazzam, H. (2016). Effect of compensation on job performance: An empirical study. International Journal of Engineering Technology, Management and Applied Science, 4(8), 103-116.

Ali, A., Bin, L. Z., Piang, H. J., \& Ali, Z. (2016). The Impact of Motivation on the Employee Performance and Job Satisfaction in IT Park (Software House) Sector of Peshawar, Pakistan. International Journal of Academic Research in Business and Social Sciences, 6(9), 297-310.
Bharata, A. (2016). The Enfluence of Compensation and Training Toward Work Discpline and its Impact On The Employees Performance In The Research Center Of Science and Technology (PUSPIPTEK). Journal The Winners, 17(1), 1-8.

Dwiputra, I. K. A., \& Satrya, I. G. B. H. (2019). Pengaruh Kepemimpinan, Motivasi dan Iklim Organisasi Terhadap Kinerja Karyawan di Warung Mina Peguyangan Denpasar. E-Jurnal Manajemen Unud, 8(1), 29182943.

Ekundayo, O. A., \& Babalola, J. A. (2018). The Impact of Motivation on Employee Performance in Selected Insurance Companies in Nigeria. International Journal of African Development, 5(1), 31-42.

Harini, S., \& Kartiwi, N. (2018). Workload, Work Environtment and Employee Performance of Housekeeping. International Journal of Latest Engineering and Management Research (IJLEMR), 3(10), 1522.

Ibrahim, A. . (2017). The Effect of Motivation on Employee Performance: Case Study In Hormuud Company in Mogadishu Somalia. International Journal of Development Research, 38(2), 130-146.

Jayanti, N. P., \& Syamsir, S. (2018). Pengaruh Lingkungan Kerja Terhadap Kinerja Perangkat Nagari Dalam Pengelolaan Keuangan Nagari Di Kabupaten Tanah Datar. JESS (Journal of Education on Social Science), 2(1), 35-46.

Kimani, N. J., Thomas, K. N., \& Arasa, R. (2017). Effect of Compensation Strategies on Employee Performance: A Case Study of Mombasa Cement Limited. International Journal of Innovative Social Sciences \& Humanities Research, 5(3), 25-42.

Mohamud, A., Ibrahim, A. A., \& Hussein, J. M. (2017). The Effect of Motivation on Employee Performance: Case Study in Hormuud Company in Mogadishu Somalia. International Journal of Development Research, 7(11), 17009-17016.

My, L. N. (2017). The Impact of Employees Motivation on Organizational Effectiveness. International Journal of Business, 9(15), 134-145.

Nurcahyani, N. M., \& Adnyani, D. (2016). Pengaruh Kompensasi dan Motivasi Terhadap Kinerja Karyawan dengan Kepuasan Kerja Sebagai Variabel Intervening. E-Jurnal Manajemen Universitas Udayana, 5(1), 500-532.

Onuorah, A. N., Okeke, M. N., \& Ikechukwu, I. A. (2019). Compensation Manajemen and Employee Performance in Nigeria. International Journal of Academic Research in Business and Social Sciences, 9(2), 384-298.

Padayachee, K. M. (2017). A Total Rewards Framework For The Attraction And Retention of The Youth. International Business \& Economic Research Journal, 1(1), 1-30.

Reddy, V. S. (2020). Impact of Compensation on Employee Performance IOSR Journal of Humanities And Social Science $\backslash$, 25(9), 17-22.

Santoni, N. P. C. C., \& Suana, I. W. (2018). Pengaruh Kompensasi, Motivasi, Disiplin Kerja Terhadap Produktivitas Kerja Karyawan Divisi Sales Honda Denpasar Agung. E-Jurnal Manajemen Unud, 7(10), 53795406.

Waeesor, E., Bin, A., Bakar, A., \& Hee, H. C. (2016). Work Motivation among Muslim Public Health Employees in Pattani Province, Thailand. Soft Science, 2(1), 162-171.

Widodo, T. W. (2018). Pengaruh Kepuasan Kerja dan Lingkungan Kerja terhadap Kinerja Karyawan Bagian Perbendaharaan dan Mobilisasi Dana RSUP Dr Sardjito. Jurnal Ekobis Dewantara, 1(9), 118-128.

Wilson, K. G. (2018). Impact of Work Environment on Academic Staff Job Performance: Case of a Uganda University. Ijame, 4(4), 95-103. 